\title{
Environmental modelling of heavy metals using pollution indices and multivariate techniques in the soils of Bahr El Baqar, Egypt
}

\author{
El-Sayed E. Omran ${ }^{1}$
}

Received: 9 June 2016/Accepted: 13 June 2016/Published online: 27 June 2016

(C) Springer International Publishing Switzerland 2016

\begin{abstract}
Fewer studies have assessed the discharge of industrial, agricultural and municipal wastewaters on heavy metal pollution in the Soils of Bahr El Baqar, Egypt. Thirty-four samples were collected and analyzed for heavy metals, which were assessed using different indices. The summary statistics results indicate that $\mathrm{Pb}, \mathrm{Cd}, \mathrm{Cu}, \mathrm{Co}, \mathrm{Cr}$ and $\mathrm{Ni}$ concentrations in Bahr El Baqar soils are higher than those in the reference soil. By applying the Pearson rank order correlations, the result revealed that these metals have the same source of contamination. Average contamination factor values for heavy metals have an order $\mathrm{Cd}>\mathrm{Cr}>\mathrm{Co}>\mathrm{Ni}>\mathrm{Cu}>\mathrm{Pb}>\mathrm{Zn}>\mathrm{Mn}>\mathrm{Fe}$, suggesting that soil samples were extremely high enriched with $\mathrm{Cd}$, while $\mathrm{Pb}$ exhibit significant enrichment. Geoaccumulation index showed that the soils of Bahr El Baqar are having high concentrations of $\mathrm{Cd}, \mathrm{Ni}, \mathrm{Co}$, and $\mathrm{Cr}$, which exceeded the average standard value. These confirmed that Bahr El Baqar drain is facing probable environmental pollution especially with dangerous heavy metals $(\mathrm{Pb}, \mathrm{Cd}, \mathrm{Co}, \mathrm{Cr}$ and $\mathrm{Ni})$. Calculation of different indices indicates the study area falls under moderate to very high contamination degree, which regarded as polluted. These indices are useful tools for identification of anthropogenic source of soil contamination. According to this study, the agricultural activity in the Bahr El Baqar area requires careful consideration.
\end{abstract}

Keywords Enrichment factor - Contamination factor . Contamination degree Geo accumulation index

El-Sayed E. Omran

ee.omran@gmail.com

1 Soil and Water Department, Faculty of Agriculture, Suez Canal University, Ismailia 41522, Egypt

\section{Introduction}

The future of soil science has been changed and the priorities have been shifted from agricultural production towards environmental and ecological issues (Omran 2008). The overexploitation of resources in agriculture has led to environmental degradation: soil erosion, the greenhouse effect, and heavy metals pollution. Contamination of agricultural soils with heavy metals has always been considered a critical challenge in the scientific community. Rapid industrialization and urbanization have led to the high accumulation of heavy metals and organic pollutants in soil, water, sediment, street dust, as well as organisms in urban areas (Chaudhari et al. 2012; El Nemr 2011; Hou et al. 2013; Hu et al. 2013; Li et al. 2013; Sedky et al. 2013). Environmental contaminations by heavy metal have been increasing interest due to their toxicity and perceived persistency (Tijani et al. 2005). These metals, which are indestructible, and non-biodegradeable, have toxic effects on living organisms, when permissible concentration levels are exceeded. Heavy metals frequently reported in the literature with regards to potential hazards and occurrences in contaminated soils are $\mathrm{Cd}, \mathrm{Cr}, \mathrm{Pb}, \mathrm{Zn}, \mathrm{Fe}$ and $\mathrm{Cu}$ (Akoto et al. 2008). Vehicle exhausts, as well as industrial activities emit these heavy metals so that soils, plants and even residents along roads with heavy traffic loads are subject to increasing levels of heavy metals contamination (Ghrefat and Yusuf 2006). Under certain environmental conditions, heavy metals might accumulate up to toxic concentration levels, and cause ecological damage (Bai et al. 2011; El Nemr et al. 2012).

Due to water scarcity, many countries, especially in arid and semiarid regions are forced to use low quality water in irrigation, which may be dangerous for environmental and human health. Polluted drains are considered a big threat to 
the surrounded environment (Hamed et al. 2011). Bahr ElBaqar is one of the most polluted drains in Egypt (AbdelShafy and Aly 2002; Abdel-Azeem et al. 2007; Omran and Abd El Razek 2012). Bahr El-Baqar drain receives and carries the greatest part of the wastewater (about $3 \mathrm{BCM}$ / year) into Lake Manzala through a very densely populated area of the Eastern Delta passing through Qalubyia, Sharkia, Ismailia and Port Said Governorates. The discharge of industrial, agricultural and municipal wastewaters in Bahr El Baqar drain which farmer uses it in irrigation led to contamination of these soils. These soils receive many kinds of pollutants, especially heavy metals such as lead, cadmium, nickel, and mercury, which are considered the most hazardous (Omran and Abd El Razek 2012; Park and Shin 2006). However, the question still not answers yet is "What is the environmental and ecological risk assessment of heavy metals of Bahr El Baqar on sustainable soil resources"? For an ecological risk assessment associated with pollutant exposure in ecosystems, several environmental factors must be considered, such as chemical, physico-chemical, biological, and ecotoxicological parameters. All these variables must be integrated and some indexes have been applied to do it. Varieties of methods have been developed for the risk assessment of heavy-metals as sediments enrichment factor, index of geological accumulation and pollution load index (Ohlson and Serveiss 2007; Serveiss 2002; Sun et al. 2010).

To the best of my knowledge, no reports are available on the different pollution indices to assess ecological risk of heavy metal contamination in Bahr El Baqar region. Therefore, the overall objective of the present study is to use geostatistical and multivariate analysis to assess the heavy metal contamination in some polluted soils of Bahr El Baqar region. Specific objectives of this study were to:

1. Assess the current level of heavy metal concentrations by different indices in the soils of Bahr El Baqar; and

2. Evaluate different pollution indices to assess the ecological and environmental risk due to soil contamination by heavy metal.

\section{Materials and methods}

\section{Overall the study area and methodology}

The study area is located in northern Egypt, Bahr El Baqar region, between $31^{\circ} 50^{\prime}$ to $32^{\circ} 20^{\prime}$ longitude and $30^{\circ} 40^{\prime}$ to $31^{\circ} 10^{\prime}$ latitude (Fig. 1). Environmental protection in Bahr El Baqar region is faced critical problems due to the increasing population, demolishing natural resources, environmental pollution, land-use planning as well as others (Omran and Abd El Razek 2012). Soils, which are adjacent to El Manzala Lake, are described as heavy saline alkali low-lying clay, which is lacustrine deposits. The land surface is flat, gently sloping towards the north and ranges in elevation from below sea level to $4 \mathrm{~m}$ a.s.1 in the highest point (Omran and Abd El Razek 2012). A reconnaissance visit was performed in the study area to get acquainted with different landscape features; land-use and land-cover patterns. A 60-km-long stretch of the Bahr El Baqar drain was selected for the present study. The extensive field surveys in August 2014 were guided with a Global Positioning System receiver. Thirtyfour soil samples were collected from Bahr El Baqar region (Fig. 1). Soils were characterized by their main physicochemical properties and by their total heavy metal contents. Soil samples were collected from selected agricultural fields. Soils were randomly sampled from the upper horizon (0-20 cm) and bulked together to form one composite sample. Soil samples were air-dried and sieved through a mesh of $<2 \mathrm{~mm}$, and then sealed in paper envelopes until analysis. The electrical conductivity (EC) of soils was determined using 1:2 soil to solution $\left(\mathrm{H}_{2} \mathrm{O}\right)$ ratio. Particle size distribution was determined by the pipette method (Gee and Bauder 1986). Soils were also characterized for their carbonate content (Allison and Moodie 1965). Soil $\mathrm{pH}$ was measured in deionized water $\left(\mathrm{pH}_{\mathrm{w}}\right)$ and in $0.01 \mathrm{M} \mathrm{CaCl}_{2}\left(\mathrm{pH}_{\mathrm{CaCl}}\right)$ (in 1:2.5 suspensions). Organic carbon (OC) was determined by the wet digestion (Walkley and Black 1934). CEC was determined for the soil samples by Na-method (Chapman 1965). Figure 2 shows the overall methodology used in this study.

\section{The selected indices and overall analysis}

The pollution indices classified from modelling point of view into two types: single indices and integrated indices (Caeiro et al. 2005). The degree of contamination in the soil is determined with the help of following indices (Table 1): enrichment factor (EF); contamination factor (CF); contamination degree (CD); pollution load index (PLI); metal pollution index (MPI) and geo accumulation index (I-geo). Many authors prefer to express the metal contamination with respect to average shale to represent the degree of quantification of pollution. Some authors have considered the background value of their area of study (Thambavani and Mageswari 2013) to be the geometric mean of concentration of the different sample sites, which is the antilog of the arithmetic average of $\log 10$ of the concentration values. According to them, the geometric mean reduces the importance of a few high values in a sample group and therefore, is numerically less than the arithmetic mean. Such background value, however, varies from place to place. As such, this methodology of 

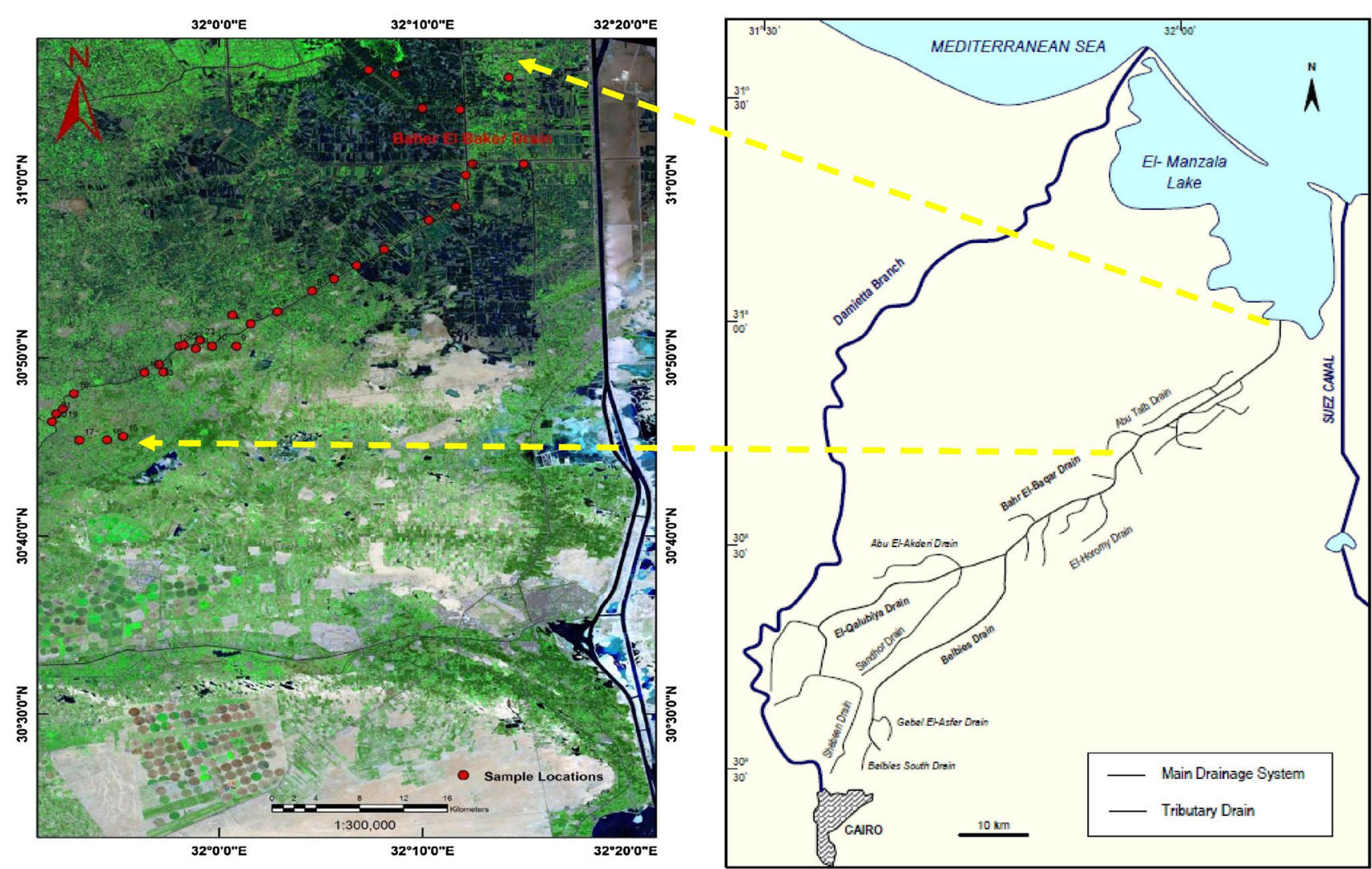

Fig. 1 Footprints and landsat-8 image for different samples locations selected for the study area

determining background value has not been considered in the present study. Instead, the world surface rock average (Omran and Abd El Razek 2012) and US EPA standard of individual metal has been taken to be the background.

\section{Geostatistical approach for interpolating soil heavy metals}

The geostatistical approach consists of two parts: calculation of an experimental variogram and the model fitting, and estimation at unsampled locations (Burgos et al. 2006). A variogram is used to measure the spatial variability of a regionalized variable and provides the input parameters for the spatial interpolation of variogram kriging (Webster and Oliver 2001). The variogram plot is fitted with a theoretical model (spherical, exponential, linear, or Gaussian). The best fitting function can be chosen by cross-validation, which checks the compatibility between the data and the model. The goodness of fit was evaluated by the mean error (unbiasedness if its value is close to 0 ) and the mean squared error, which should equal the kriging variance, and the root mean square error (should be 1). The fitted model provides information about the spatial structure as well as the input parameters for kriging interpolation (Burgos et al. 2006). After selecting an appropriate variogram model, the parameters can be used with the data to predict heavy metal concentrations at unsampled locations using kriging. Kriging is the most popular generalized linear regression techniques for minimizing and estimating variance in an unsampled location (Webster and Oliver 2001). The selection of a kriging algorithm (ordinary, simple, universal kriging, etc.) model should be guided by the characteristic of the data under study (Saito and Goovaerts 2000). Geostatistical analyses were performed using the Geostatistical analyst extension available in ESRI ArcMap v 10.2

\section{Results and discussion}

\section{Physico-chemical properties of the Bahr El Baqar soils}

The $\mathrm{pH}, \mathrm{CEC}$, clay and organic matter contents $(\mathrm{OM})$ are the principal soil characteristics that determine the capacity to retain heavy metal pollutants. The average of $\mathrm{pH}$ in Bahr El Baqar soils is about 8.00 , because of the presence of calcareous parent material (Table 2). The $\mathrm{pH}$ of the soil solution maintained at alkaline condition showed low mobility of all heavy metals. It could be attributed to the presence of carbonates at a high concentration. The high 


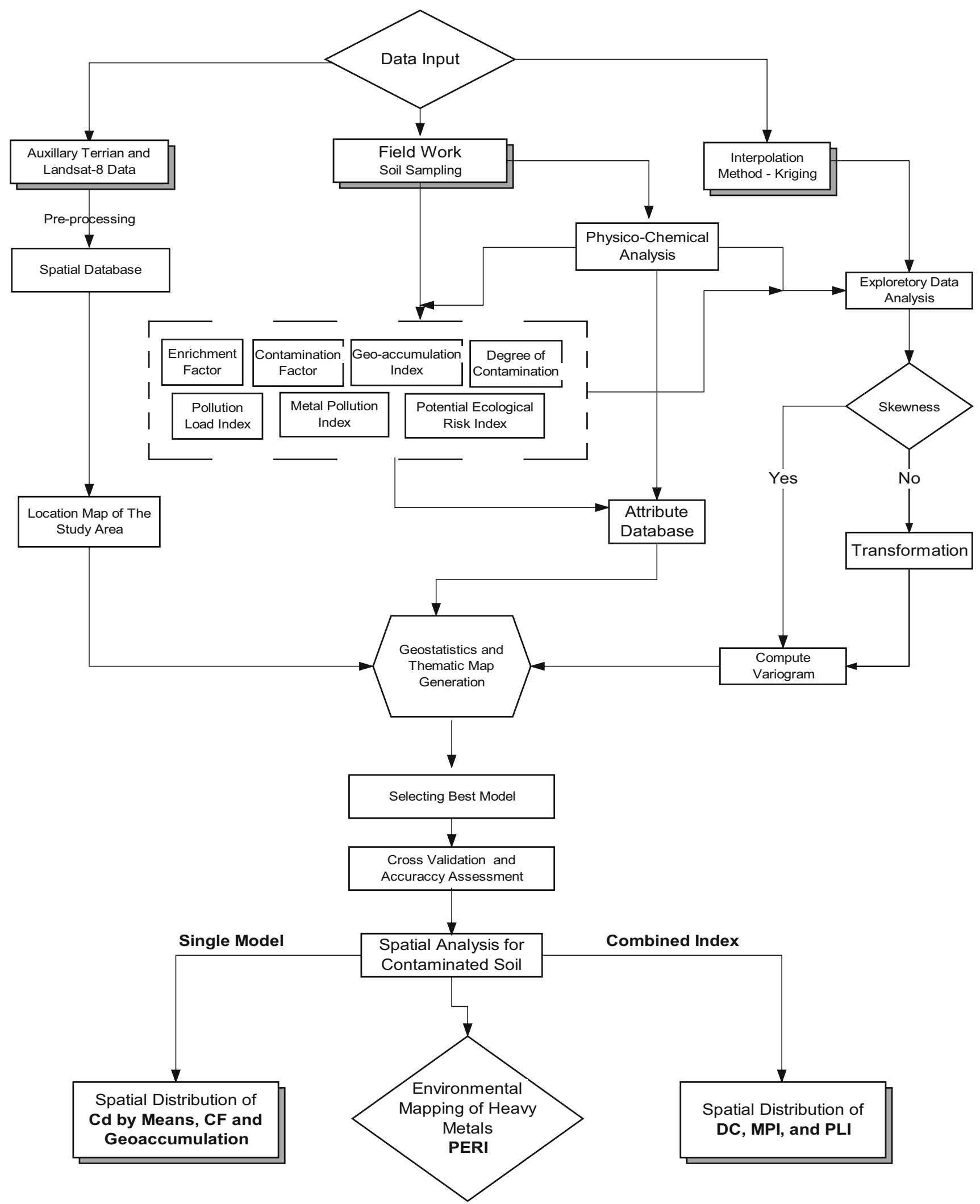

Fig. 2 Methodology and procedure used to assess the heavy metals in the soils of Bahr El Baqar, Egypt 


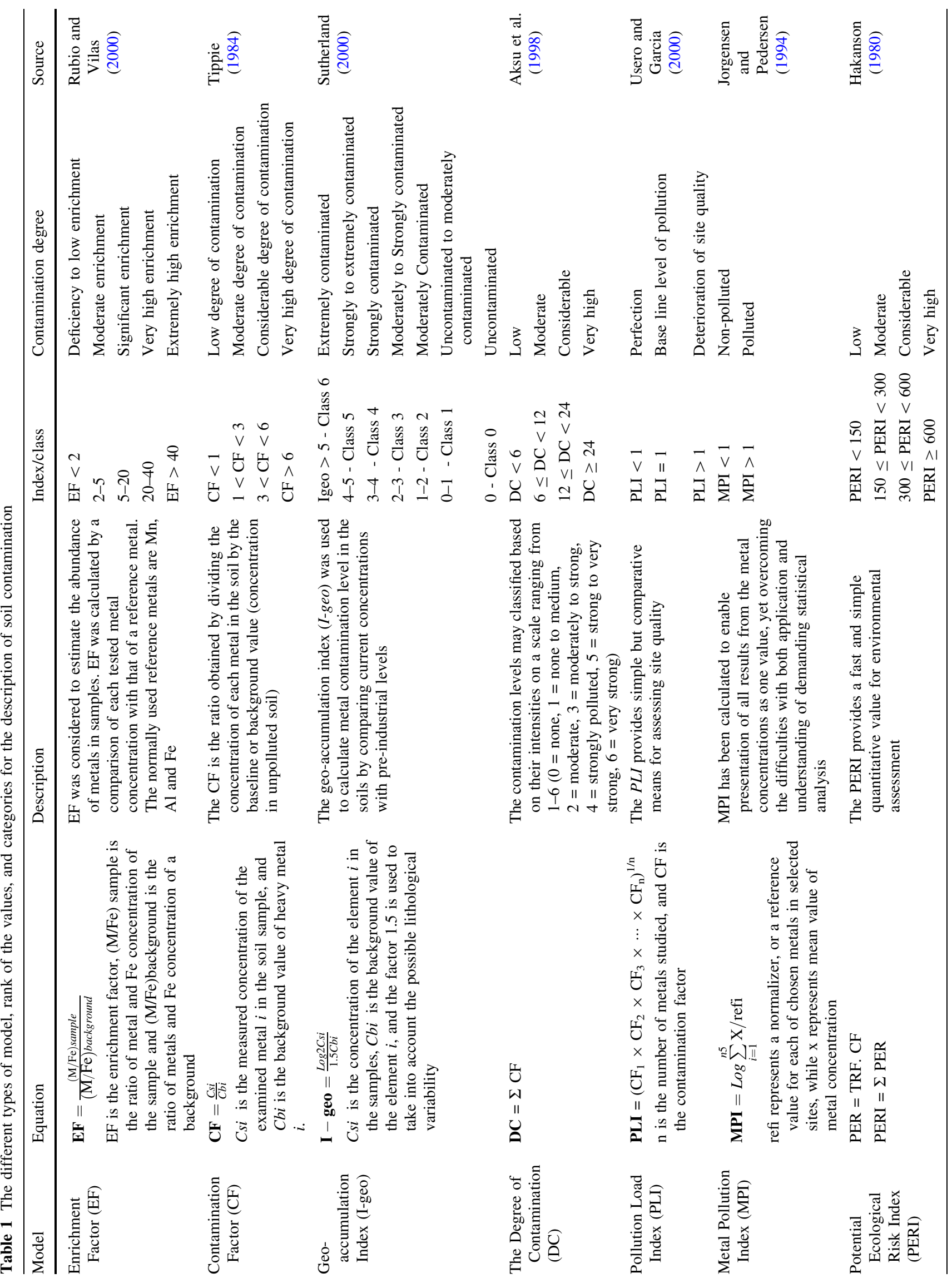


Table 2 Summary statistics of soil physico-chemical properties of the Bahr El Baqar

\begin{tabular}{lrrrrrrrr}
\hline Properties & Minimum & Maximum & Range & Mean & Std. deviation & CV & Skewness & Kurtosis \\
\hline $\mathrm{Fe}$ & 7.80 & 87.96 & 80.16 & 47.45 & 25.19 & 634.38 & -0.04 & -1.31 \\
$\mathrm{Mn}$ & 13.73 & 98.73 & 85.00 & 58.98 & 23.39 & 547.26 & -0.32 & -0.81 \\
$\mathrm{Cu}$ & 7.73 & 280.30 & 272.58 & 65.70 & 54.68 & 2990.45 & 2.27 & 6.69 \\
$\mathrm{Zn}$ & 39.67 & 215.58 & 175.91 & 90.56 & 41.86 & 1752.64 & 0.76 & 0.76 \\
$\mathrm{Ni}$ & 61.32 & 88.73 & 27.41 & 73.22 & 7.96 & 63.34 & 0.74 & -0.41 \\
$\mathrm{~Pb}$ & 24.42 & 52.40 & 27.98 & 36.64 & 7.04 & 49.63 & 0.58 & 0.05 \\
$\mathrm{Cd}$ & 10.27 & 19.07 & 8.80 & 14.69 & 2.31 & 5.32 & 0.06 & -0.44 \\
$\mathrm{Co}$ & 70.51 & 113.82 & 43.31 & 89.72 & 12.58 & 158.29 & 0.66 & -0.71 \\
$\mathrm{Cr}$ & 84.92 & 134.06 & 49.14 & 106.96 & 12.26 & 150.23 & 0.16 & 0.07 \\
$\mathrm{CEC}$ & 4.79 & 96.75 & 91.96 & 45.00 & 25.33 & 641.77 & 0.80 & -0.50 \\
$\mathrm{Total} \mathrm{N}$ & 2.38 & 7.70 & 5.32 & 4.58 & 1.28 & 1.63 & 0.71 & 0.33 \\
$\mathrm{OM}$ & 0.22 & 3.55 & 3.33 & 1.60 & 0.79 & 0.62 & 0.73 & 0.69 \\
$\mathrm{pH}$ & 7.58 & 8.82 & 1.24 & 8.00 & 0.30 & 0.09 & 0.81 & 0.25 \\
$\mathrm{CaCO}{ }_{3}$ & 0.61 & 29.20 & 28.59 & 6.58 & 8.77 & 76.93 & 1.70 & 1.44 \\
$\mathrm{Sand}$ & 2.60 & 95.72 & 93.12 & 43.00 & 25.83 & 667.07 & 0.16 & -0.78 \\
$\mathrm{Silt}$ & 1.04 & 56.89 & 55.85 & 30.38 & 12.93 & 167.09 & -0.20 & 0.43 \\
$\mathrm{Clay}$ & 3.24 & 80.00 & 76.76 & 26.61 & 24.52 & 601.14 & 1.01 & -0.51 \\
\hline
\end{tabular}

$\mathrm{Fe}, \mathrm{Mn}, \mathrm{Cu}, \mathrm{Zn}, \mathrm{Pb}, \mathrm{Cd}, \mathrm{Co}, \mathrm{Cr}$ are in $\mathrm{mg} \mathrm{kg}^{-1}, \mathrm{CEC} \mathrm{Cmolc/Kg}, \mathrm{N} \mathrm{mg/gm}, \mathrm{OM}, \mathrm{CaCO}_{3}$, sand, silt, clay are in $\%$
$\mathrm{pH}$ value measured in soils potentially limits the risk of metal mobilization. The relatively high content of $\mathrm{OM}$ $(1.6 \%)$ is mainly related to the high organic matter flux to the soil due to direct discharge of domestic and industrial wastewaters. Soil organic matter is a key for sorbing phase of metals. The dissolution of humic acid at high $\mathrm{pH}$ is responsible for the dissolution of $\mathrm{Cu}$ and $\mathrm{Pb}$ from the soil. Organic matter is important for the retention of metals by soil solids, thus decreasing mobility and bioavailability.

The summary statistics results indicate that the mean value of soil $\mathrm{Pb}, \mathrm{Cu}, \mathrm{Cr}$ and $\mathrm{Zn}$ concentrations is 36.64, $65.70,106.96$, and $90.56 \mathrm{mg} \mathrm{kg}^{-1}$, respectively and the range between the minimum and maximum values is 27.98 , $272.58,49.14$, and $175.91 \mathrm{mg} \mathrm{kg}^{-1}$, respectively, which is large. There are great variations and high skewness for $\mathrm{Cu}$ and $\mathrm{Zn}(2.27$ and 0.76$)$. The $\mathrm{CV} \%$ values reflect the mean variation of each sampling site in the population. The order of the $\mathrm{CV} \% \mathrm{~s}$ for each element, from high to low, was $\mathrm{Cu}>\mathrm{Zn}>\mathrm{Fe}>\mathrm{Mn}>\mathrm{Co}>\mathrm{Cr}>\mathrm{Ni}>\mathrm{Pb}>\mathrm{Cd}$. This result showed that the variation of $\mathrm{Cu}$ and $\mathrm{Zn}$ in the soil was larger than other metals.

The mean concentration of metals at selected locations and their world surface rock average is given in Table 3 . The mean value of soil $\mathrm{Cu}, \mathrm{Ni}, \mathrm{Pb}, \mathrm{Cd}, \mathrm{Co}$ and $\mathrm{Cr}$ concentrations is $65.70,73.22,36.64,14.69,89.72$, and $106.96 \mathrm{mg} \mathrm{kg}^{-1}$, respectively, which is much higher than the US EPA threshold level $(16,16,20,0.6,23$, and $26 \mathrm{mg} \mathrm{kg}^{-1}$, respectively) presented in Table 3 . This result shows that $\mathrm{Pb}, \mathrm{Cd}, \mathrm{Cu}, \mathrm{Co}, \mathrm{Cr}$ and $\mathrm{Ni}$ concentrations in
Bahr El Baqar soil are higher than those in the reference soil. These levels are far above the average concentrations in the earth's crust (Hasan 2007; Yobouet et al. 2010) and the threshold concentration of European Union Standards. Table 3 indicates these soils are heavily polluted with heavy metals that are part of the most dangerous industrial and municipal waste (Hasan 2007). The ranking order of mean values of the heavy metals in the Bahr El Baqar soils followed the sequence: $\mathrm{Cr}>\mathrm{Zn}>\mathrm{Co}>\mathrm{Ni}>\mathrm{Cu}>\mathrm{Mn}>$ $\mathrm{Fe}>\mathrm{Pb}>\mathrm{Cd}$.

\section{Multivariate statistical analysis}

Multivariate analysis (i.e., Principal component analysis; and correlation) has been proved to be an effective tool for providing suggestive information regarding heavy metal sources and pathways (Hu et al. 2013).

\section{Factor analysis}

Table 4 shows a factor analysis, which was, performed on raw data in an attempt to further clarify the major controlling factors that determine the heavy metal's distribution in the Bahr El Baqar soils. Four of the factors, which account for most of the variability in the 17 variables, were obtained. Four factors have been extracted which had eigenvalues greater than or equal to 1 . Together they account for $78.11 \%$ of the variability in the original data (Table 4). The types of factoring have been selected as 
Table 3 Comparison of heavy metal concentrations $\left(\mathrm{mg} \mathrm{kg}^{-1}\right)$ with those of the threshold and the Earth's crust

\begin{tabular}{|c|c|c|c|c|c|c|c|c|c|}
\hline Parameters & $\mathrm{Fe}$ & $\mathrm{Mn}$ & $\mathrm{Cu}$ & $\mathrm{Zn}$ & $\mathrm{Ni}$ & $\mathrm{Pb}$ & $\mathrm{Cd}$ & Co & $\mathrm{Cr}$ \\
\hline Values obtained from present study & 47.45 & 58.98 & 65.70 & 90.56 & 73.22 & 36.64 & 14.69 & 89.72 & 106.96 \\
\hline Average concentration in the Earth's crust* & 56,300 & 850 & 55 & 70 & 75 & 12.5 & 0.15 & - & 100 \\
\hline Extremes values recorded in shale** & 46,700 & 950 & 40 & 95 & 68 & 20 & 0.3 & - & 90 \\
\hline Threshold concentration***EUS & - & - & 140 & 300 & 75 & 300 & 3 & - & 150 \\
\hline US EPA, 1993 & 267.00 & 72.00 & 16.00 & 95 & 16.00 & 20 & 0.6 & 23 & 26 \\
\hline
\end{tabular}

* Taylor 1964; ** Turekian and Wedepohl 1961; *** European Union 2002

Table 4 Factor loading component matrix after varimax rotation

\begin{tabular}{|c|c|c|c|c|}
\hline & 1 & 2 & 3 & 4 \\
\hline CEC & 0.077 & 0.154 & 0.944 & 0.144 \\
\hline Total N & 0.332 & -0.500 & 0.377 & 0.086 \\
\hline $\mathrm{OM}$ & 0.696 & -0.171 & -0.011 & 0.514 \\
\hline $\mathrm{pH}$ & -0.222 & 0.042 & 0.662 & -0.098 \\
\hline $\mathrm{CaCO}_{3}$ & -0.078 & 0.067 & 0.812 & 0.393 \\
\hline Sand & -0.406 & 0.092 & -0.292 & 0.038 \\
\hline Silt & 0.023 & -0.586 & 0.676 & -0.271 \\
\hline Clay & -0.048 & 0.212 & 0.943 & 0.103 \\
\hline $\mathrm{Fe}$ & 0.832 & -0.088 & 0.305 & -0.047 \\
\hline $\mathrm{Mn}$ & -0.058 & -0.235 & 0.410 & 0.777 \\
\hline $\mathrm{Cu}$ & 0.754 & 0.150 & -0.250 & -0.001 \\
\hline $\mathrm{Zn}$ & -0.021 & 0.311 & -0.144 & 0.738 \\
\hline $\mathrm{Ni}$ & 0.472 & -0.636 & 0.464 & 0.163 \\
\hline $\mathrm{Pb}$ & 0.249 & 0.621 & -0.173 & -0.578 \\
\hline $\mathrm{Cd}$ & -0.658 & -0.413 & -0.304 & 0.371 \\
\hline Co & -0.584 & 0.511 & 0.482 & 0.223 \\
\hline $\mathrm{Cr}$ & 0.166 & 0.683 & 0.401 & 0.087 \\
\hline Variance $\%$ & 47.244 & 13.652 & 10.718 & 6.492 \\
\hline Cumulative $\%$ & 47.244 & 60.896 & 71.615 & 78.107 \\
\hline
\end{tabular}

Extraction method: principal component analysis

principal components. Metal loadings of the factors have been given in Table 4. Factor 1 accounts for $47.24 \%$ of the variability in the original data. The first group of variables can be described as an anthropogenic assemblage composed of mainly $\mathrm{Fe}, \mathrm{Co}, \mathrm{Cd}, \mathrm{Cu}$ and $\mathrm{OM}$. This factor reflects the binding of heavy metals to organic matter. Factor 2 accounts for $13.65 \%$ of the variability in the original data. The second group of anthropogenic variables composed of mainly $\mathrm{Ni}, \mathrm{Cr}$ and $\mathrm{Pb}$. Factor 3 accounts for $10.72 \%$ of the variability in the original data and explains metal sorbtion pools: carbonates, alumino silicates (clay minerals), $\mathrm{pH}$ and CEC. The first two of them resulted from terrestrial sources. Both of them are conservative components and they lose some trace metal contents via resuspension by the winds. Factor 4 accounts for $6.49 \%$ of the variability in the original data and is composed of mainly $\mathrm{Mn}$ and $\mathrm{Zn}$.

\section{Statistical analyses}

By applying the Pearson (parametric) rank order correlations (Table 5), the results revealed that the $\mathrm{Fe}$ is well correlated with $\mathrm{Mn}$ and moderately correlated with $\mathrm{Cu}$ and $\mathrm{Zn} \quad(\mathrm{r}=0.819,0.488,0.471$ respectively). Furthermore, there is a good correlation between $\mathrm{Ni}$ and $\mathrm{Co}(\mathrm{r}=0.966)$. There are significant correlations between $\mathrm{Cu}$ and each of $\mathrm{Zn}, \mathrm{Pb},(\mathrm{r}=0.678,0.544$, respectively) as shown in Table 5. This result revealed that these metals have the same source of contamination. The results in Table 5 also showed that $\mathrm{Ni}, \mathrm{Fe}, \mathrm{Mn}, \mathrm{Cu}, \mathrm{Zn}$ and $\mathrm{Co}$ are positively correlated with $\mathrm{OM}, \mathrm{pH}$ and clay, $\mathrm{CaCO}_{3}$, and $\mathrm{CEC}$ and of course negatively correlated with sand. Clay highly correlated with $\mathrm{Fe}, \mathrm{Mn}, \mathrm{Cu}$, and $\mathrm{Zn}(0.773,0.658,0.786$, and 0.709 respectively).

\section{Quantification of heavy metals accumulation}

\section{Single models}

Table 6 shows the results of contamination factor (CF). As shown in Table 6 , average $\mathrm{CF}$ values for heavy metals have an order $\mathrm{Cd}>\mathrm{Cr}>\mathrm{Co}>\mathrm{Ni}>\mathrm{Cu}>\mathrm{Pb}>\mathrm{Zn}>\mathrm{Mn}>$ $\mathrm{Fe}$, suggesting that soil samples was extremely high enrichment with $\mathrm{Cd}$, while $\mathrm{Pb}$ exhibit significant enrichment. In contrast, the rest of the metals show moderate or minimal enrichment in the study area. With respect to specific sites, high $\mathrm{CF}$ values for $\mathrm{Cd}$ (e.g., 31.79 were found in samples 10, 18, and 23. High CF values for $\mathrm{Cr}$ (5.16) were found in sample 5. High CF values for Co (4.95) were found in samples 6 and 19. However, for $\mathrm{Cu}$, most of the locations have moderate to considerable contamination except samples of 26 and 27 which very highly contaminated. These locations were located at the downstream and continuously receive a vast amount of wastewater and other wastes of the city. Results in Table 6 show the $\mathrm{CF}$ values of most of the $\mathrm{Mn}, \mathrm{Zn}$, and Fe metals in the study area, which are low degree of contamination. Nevertheless, $\mathrm{CF}$ values for metals like $\mathrm{Ni}, \mathrm{Cd}$ and $\mathrm{Cr}$ shows considerable degree. This is due to the influence of external discrete sources like industrial activities, 


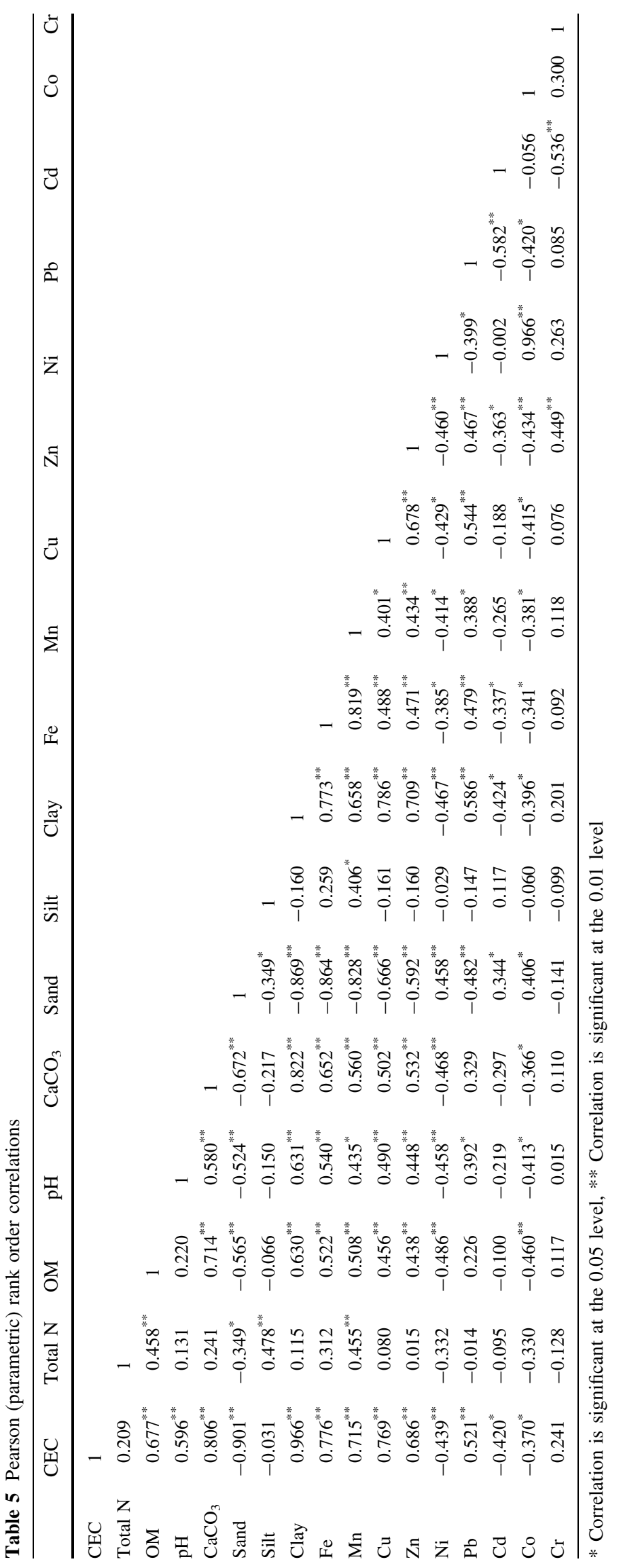


Table 6 Contamination factor (CF) for heavy metal accumulation in the study area

\begin{tabular}{|c|c|c|c|c|c|c|c|c|c|}
\hline Sampling point & $\mathrm{Fe}$ & $\mathrm{Mn}$ & $\mathrm{Cu}$ & $\mathrm{Zn}$ & $\mathrm{Ni}$ & $\mathrm{Pb}$ & $\mathrm{Cd}$ & Co & $\mathrm{Cr}$ \\
\hline P1 & 0.18 & 0.90 & 2.11 & 0.91 & 4.32 & 1.61 & 25.81 & 3.41 & 4.06 \\
\hline $\mathrm{P} 2$ & 0.17 & 0.96 & 3.03 & 0.64 & 4.90 & 1.22 & 28.06 & 4.38 & 4.69 \\
\hline P3 & 0.20 & 0.97 & 2.94 & 0.43 & 5.44 & 1.70 & 22.25 & 4.80 & 4.17 \\
\hline P4 & 0.13 & 0.72 & 2.52 & 0.42 & 4.40 & 1.73 & 22.47 & 3.85 & 3.55 \\
\hline P5 & 0.06 & 0.76 & 5.39 & 1.60 & 4.41 & 1.59 & 21.58 & 3.94 & 5.16 \\
\hline P6 & 0.27 & 0.90 & 2.04 & 1.05 & 5.55 & 1.53 & 26.98 & 4.95 & 4.21 \\
\hline P7 & 0.27 & 1.11 & 2.62 & 0.60 & 4.62 & 2.04 & 25.36 & 3.83 & 4.14 \\
\hline P8 & 0.03 & 0.19 & 1.24 & 0.43 & 5.44 & 1.70 & 22.25 & 4.80 & 4.17 \\
\hline P9 & 0.03 & 0.37 & 0.48 & 1.08 & 4.57 & 2.05 & 26.19 & 3.84 & 4.13 \\
\hline P10 & 0.05 & 0.91 & 1.87 & 0.44 & 4.26 & 1.46 & 31.79 & 3.66 & 3.27 \\
\hline P11 & 0.06 & 0.75 & 2.20 & 0.91 & 4.36 & 1.65 & 26.14 & 3.42 & 4.04 \\
\hline P12 & 0.14 & 1.06 & 2.74 & 0.63 & 4.46 & 1.94 & 27.69 & 3.57 & 3.70 \\
\hline P13 & 0.20 & 0.89 & 6.14 & 1.48 & 4.14 & 2.62 & 19.25 & 3.48 & 4.56 \\
\hline P14 & 0.15 & 0.82 & 2.17 & 0.91 & 4.32 & 1.61 & 25.81 & 3.41 & 4.06 \\
\hline P15 & 0.07 & 0.29 & 1.11 & 0.64 & 4.90 & 1.22 & 28.06 & 4.38 & 4.69 \\
\hline P16 & 0.06 & 0.39 & 1.53 & 0.43 & 5.44 & 1.70 & 22.25 & 4.80 & 4.17 \\
\hline P17 & 0.11 & 0.27 & 0.86 & 0.42 & 4.40 & 1.73 & 22.47 & 3.85 & 3.55 \\
\hline P18 & 0.17 & 0.67 & 6.19 & 1.15 & 4.26 & 1.46 & 31.79 & 3.66 & 3.27 \\
\hline P19 & 0.08 & 0.48 & 4.75 & 1.05 & 5.55 & 1.53 & 26.98 & 4.95 & 4.21 \\
\hline P20 & 0.17 & 0.37 & 1.28 & 0.60 & 4.62 & 2.04 & 25.36 & 3.83 & 4.14 \\
\hline P21 & 0.06 & 0.41 & 1.51 & 0.43 & 5.44 & 1.70 & 22.25 & 4.80 & 4.17 \\
\hline P22 & 0.10 & 0.47 & 5.31 & 1.08 & 4.57 & 2.05 & 26.19 & 3.84 & 4.13 \\
\hline P23 & 0.19 & 0.73 & 1.90 & 0.44 & 4.26 & 1.46 & 31.79 & 3.66 & 3.27 \\
\hline P24 & 0.24 & 0.94 & 2.71 & 0.91 & 4.36 & 1.65 & 26.14 & 3.42 & 4.04 \\
\hline P25 & 0.21 & 1.04 & 5.81 & 1.12 & 4.46 & 1.92 & 27.02 & 3.57 & 3.72 \\
\hline P26 & 0.27 & 0.91 & 17.52 & 1.58 & 4.02 & 2.53 & 21.30 & 3.22 & 4.07 \\
\hline P27 & 0.28 & 1.11 & 12.57 & 1.21 & 4.03 & 2.23 & 28.95 & 3.28 & 3.65 \\
\hline P28 & 0.27 & 0.96 & 8.75 & 2.27 & 3.89 & 2.09 & 19.85 & 3.07 & 4.46 \\
\hline P29 & 0.30 & 1.18 & 5.39 & 1.60 & 4.41 & 1.59 & 21.58 & 3.94 & 5.16 \\
\hline P30 & 0.30 & 1.37 & 3.86 & 1.07 & 4.89 & 2.21 & 17.12 & 4.32 & 4.59 \\
\hline P31 & 0.32 & 1.28 & 4.04 & 1.04 & 3.96 & 2.25 & 17.28 & 3.47 & 3.90 \\
\hline P32 & 0.33 & 1.18 & 4.80 & 1.10 & 3.83 & 1.90 & 24.45 & 3.30 & 3.59 \\
\hline P33 & 0.30 & 1.19 & 6.10 & 1.27 & 4.99 & 1.99 & 20.75 & 4.45 & 4.63 \\
\hline P34 & 0.30 & 1.34 & 6.14 & 1.48 & 4.14 & 2.62 & 19.25 & 3.48 & 4.56 \\
\hline Grade & 1 & $1-2$ & $2-3$ & $1-2$ & 3 & 2 & 4 & 3 & 3 \\
\hline
\end{tabular}

agricultural and other anthropogenic inputs. Only, $\mathrm{Cd}$ shows a high degree of contamination.

Table 7 presents the geo-accumulation index for the quantification of heavy metal accumulation in the study area. The I-geo grade for the study area varies from metal to metal and location to location (across metals and locations). Fe remains in grade 0 (unpolluted) in all locations suggesting that the study area soils are in background value with respect to this metal. The I-geo for $\mathrm{Mn}$ and $\mathrm{Zn}$ attain grade 0 in few locations (unpolluted), while, attain in grade 1 in other soils which indicates that these soils were slightly polluted by Mn and Zn. I-geo index showed that most of $(\mathrm{Ni}, \mathrm{Co}, \mathrm{Cr}$ ) heavy metals are in grade 3 (Table 7). $\mathrm{Pb}$ and $\mathrm{Cu}$ are in grade 2 , however, $\mathrm{Cd}$ is in grade 6 . This suggests that the soils of Bahr El Baqar are having background concentrations and these elements are practically changed by anthropogenic influences, while the concentration of $\mathrm{Cd}, \mathrm{Ni} \mathrm{Co}$, and $\mathrm{Cr}$ exceeded the average standard value. These dangerous metals may be derived from industrial waste and gasoline additives used, in the factories and cars (Mwamburi 2003). These elements may also be derived through corrosion of the numerous abandoned launches along the drain and agricultural activities.

\section{Combined index}

Table 8 shows different combined indices for heavy metal accumulation in the study area. DC values characterize a 
Table 7 The geo-accumulation index for the quantification of heavy metal accumulation in the study area

\begin{tabular}{|c|c|c|c|c|c|c|c|c|c|}
\hline Sampling point & $\mathrm{Fe}$ & $\mathrm{Mn}$ & $\mathrm{Cu}$ & $\mathrm{Zn}$ & $\mathrm{Ni}$ & $\mathrm{Pb}$ & $\mathrm{Cd}$ & Co & $\mathrm{Cr}$ \\
\hline P1 & -1.90 & 0.43 & 1.66 & 0.45 & 2.70 & 1.27 & 5.27 & 2.35 & 2.61 \\
\hline $\mathrm{P} 2$ & -2.01 & 0.52 & 2.18 & -0.06 & 2.88 & 0.87 & 5.40 & 2.72 & 2.81 \\
\hline P3 & -1.71 & 0.54 & 2.14 & -0.64 & 3.03 & 1.35 & 5.06 & 2.85 & 2.65 \\
\hline P4 & -2.31 & 0.11 & 1.92 & -0.67 & 2.72 & 1.37 & 5.07 & 2.53 & 2.41 \\
\hline P5 & -3.55 & 0.19 & 3.01 & 1.27 & 2.73 & 1.25 & 5.02 & 2.56 & 2.95 \\
\hline P6 & -1.32 & 0.42 & 1.62 & 0.65 & 3.06 & 1.20 & 5.34 & 2.89 & 2.66 \\
\hline P7 & -1.29 & 0.73 & 1.97 & -0.16 & 2.79 & 1.62 & 5.25 & 2.52 & 2.63 \\
\hline P8 & -4.51 & -1.81 & 0.89 & -0.64 & 3.03 & 1.35 & 5.06 & 2.85 & 2.65 \\
\hline P9 & -4.33 & -0.86 & -0.47 & 0.70 & 2.78 & 1.62 & 5.30 & 2.52 & 2.63 \\
\hline P10 & -3.74 & 0.46 & 1.48 & -0.59 & 2.68 & 1.13 & 5.58 & 2.46 & 2.29 \\
\hline P11 & -3.57 & 0.16 & 1.72 & 0.46 & 2.71 & 1.30 & 5.29 & 2.36 & 2.60 \\
\hline $\mathrm{P} 12$ & -2.21 & 0.67 & 2.04 & -0.07 & 2.74 & 1.54 & 5.38 & 2.42 & 2.47 \\
\hline P13 & -1.70 & 0.41 & 3.20 & 1.15 & 2.63 & 1.97 & 4.85 & 2.38 & 2.77 \\
\hline P14 & -2.16 & 0.30 & 1.70 & 0.45 & 2.70 & 1.27 & 5.27 & 2.35 & 2.61 \\
\hline P15 & -3.32 & -1.22 & 0.73 & -0.06 & 2.88 & 0.87 & 5.40 & 2.72 & 2.81 \\
\hline P16 & -3.42 & -0.76 & 1.20 & -0.64 & 3.03 & 1.35 & 5.06 & 2.85 & 2.65 \\
\hline P17 & -2.61 & -1.32 & 0.36 & -0.67 & 2.72 & 1.37 & 5.07 & 2.53 & 2.41 \\
\hline P18 & -1.98 & 0.01 & 3.21 & 0.78 & 2.68 & 1.13 & 5.58 & 2.46 & 2.29 \\
\hline P19 & -3.00 & -0.46 & 2.83 & 0.65 & 3.06 & 1.20 & 5.34 & 2.89 & 2.66 \\
\hline P20 & -1.97 & -0.86 & 0.94 & -0.16 & 2.79 & 1.62 & 5.25 & 2.52 & 2.63 \\
\hline P21 & -3.55 & -0.71 & 1.18 & -0.64 & 3.03 & 1.35 & 5.06 & 2.85 & 2.65 \\
\hline P22 & -2.80 & -0.52 & 2.99 & 0.70 & 2.78 & 1.62 & 5.30 & 2.52 & 2.63 \\
\hline P23 & -1.82 & 0.13 & 1.51 & -0.59 & 2.68 & 1.13 & 5.58 & 2.46 & 2.29 \\
\hline P24 & -1.48 & 0.49 & 2.02 & 0.46 & 2.71 & 1.30 & 5.29 & 2.36 & 2.60 \\
\hline P25 & -1.70 & 0.64 & 3.12 & 0.74 & 2.74 & 1.53 & 5.34 & 2.42 & 2.48 \\
\hline P26 & -1.31 & 0.45 & 4.72 & 1.25 & 2.59 & 1.92 & 5.00 & 2.27 & 2.61 \\
\hline P27 & -1.25 & 0.73 & 4.24 & 0.86 & 2.59 & 1.74 & 5.44 & 2.30 & 2.45 \\
\hline P28 & -1.32 & 0.53 & 3.71 & 1.77 & 2.54 & 1.65 & 4.90 & 2.20 & 2.74 \\
\hline P29 & -1.15 & 0.82 & 3.01 & 1.27 & 2.73 & 1.25 & 5.02 & 2.56 & 2.95 \\
\hline P30 & -1.17 & 1.04 & 2.53 & 0.68 & 2.88 & 1.73 & 4.68 & 2.69 & 2.78 \\
\hline P31 & -1.07 & 0.94 & 2.60 & 0.65 & 2.57 & 1.75 & 4.70 & 2.38 & 2.55 \\
\hline P32 & -1.02 & 0.82 & 2.85 & 0.73 & 2.52 & 1.51 & 5.20 & 2.31 & 2.43 \\
\hline P33 & -1.17 & 0.84 & 3.19 & 0.93 & 2.90 & 1.57 & 4.96 & 2.74 & 2.80 \\
\hline P34 & -1.17 & 1.00 & 3.20 & 1.15 & 2.63 & 1.97 & 4.85 & 2.38 & 2.77 \\
\hline Grade & $0-1$ & 1 & 2 & 1 & 3 & 2 & 6 & 3 & 3 \\
\hline
\end{tabular}

very high pollution for all of the Bahr El Baqar soils, reflecting the changes in soil occupation and the intensity of economic activities. The soils no. 26 and 18 is the most contaminated soils which shows the highest DC value of all studied areas (55.41 and 52.61) which classified as very high. The soils no. 31 and 17 show lowest DC values (37.54 and 37.65). Pollution severity and its variation along the sites was determined with the use of pollution load index. This index is a quick tool in order to compare the pollution status of different places. The values of the Pollution Load Indexes (Table 7) were found to be generally polluted $(>1)$ in all the studied soils. The difference in indices results due to the difference in sensitivity of these indices towards the soil pollutants (Praveena et al. 2007).
These confirmed that Bahr El Baqar drain is facing probable environmental pollution, especially with dangerous heavy metals $(\mathrm{Pb}, \mathrm{Cd}, \mathrm{Co}, \mathrm{Cr}$ and $\mathrm{Ni}$ ) which result from increased rate of non-treated industrial waste which are discharged to Bahr El Baqar drain. If this combined index (MPI) is above 1 , the concentrations of trace metals would be considered elevated and ecosystem could be regarded as "polluted".

\section{The potential ecological risk index}

Table 9 summarizes the results for PERI calculation at the studied areas. CF increment generates an equal increase of $\mathrm{DC}$, since $\mathrm{DC}=\Sigma \mathrm{CF}$, but PERI increment will depend on 
Table 8 Different combined indices for heavy metal's accumulation in the study area

\begin{tabular}{llllllll}
\hline Sampling point & DC & MPI & PLI & Sampling point & DC & MPI & PLI \\
\hline P1 & 43.30 & 1.64 & 2.09 & P18 & 52.61 & 1.72 & 2.31 \\
P2 & 48.04 & 1.68 & 2.17 & P19 & 49.57 & 1.70 & 2.14 \\
P3 & 42.90 & 1.63 & 2.16 & P20 & 42.41 & 1.63 & 1.78 \\
P4 & 39.78 & 1.60 & 1.84 & P21 & 40.76 & 1.61 & 1.58 \\
P5 & 44.49 & 1.65 & 2.19 & P22 & 47.73 & 1.68 & 2.15 \\
P6 & 47.46 & 1.68 & 2.38 & P23 & 47.70 & 1.68 & 1.86 \\
P7 & 44.59 & 1.65 & 2.30 & P24 & 44.40 & 1.65 & 2.24 \\
P8 & 40.25 & 1.60 & 1.32 & P25 & 48.88 & 1.69 & 2.53 \\
P9 & 42.74 & 1.63 & 1.43 & P26 & 55.41 & 1.74 & 2.99 \\
P10 & 47.71 & 1.68 & 1.65 & P27 & 57.31 & 1.76 & 2.90 \\
P11 & 43.52 & 1.64 & 1.82 & P28 & 45.61 & 1.66 & 2.82 \\
P12 & 45.95 & 1.66 & 2.11 & P29 & 45.15 & 1.65 & 2.76 \\
P13 & 42.76 & 1.63 & 2.60 & P30 & 39.73 & 1.60 & 2.64 \\
P14 & 43.25 & 1.64 & 2.04 & P31 & 37.54 & 1.57 & 2.48 \\
P15 & 45.35 & 1.66 & 1.53 & P32 & 44.48 & 1.65 & 2.54 \\
P16 & 40.78 & 1.61 & 1.59 & P33 & 45.66 & 1.66 & 2.83 \\
P17 & 37.65 & 1.58 & 1.43 & P34 & 43.30 & 1.64 & 2.84 \\
Grade & Very high & Polluted & Polluted & Grade & Very high & Polluted & Polluted \\
\hline
\end{tabular}

Table 9 Potential ecological risk (PER) values and the results for PERI calculation at the studied areas

\begin{tabular}{lrllllllrlrrrr}
\hline Sampling point & \multicolumn{1}{l}{$\mathrm{Cu}$} & $\mathrm{Zn}$ & $\mathrm{Pb}$ & $\mathrm{Cd}$ & $\mathrm{Cr}$ & $\mathrm{PERI}$ & Sampling point & $\mathrm{Cu}$ & $\mathrm{Zn}$ & $\mathrm{Pb}$ & $\mathrm{Cd}$ & $\mathrm{Cr}$ & $\mathrm{PERI}$ \\
\hline P1 & 10.88 & 0.93 & 8.29 & 796.96 & 8.36 & 825.42 & $\mathrm{P} 18$ & 31.33 & 1.16 & 7.39 & 965.56 & 6.61 & 1012.06 \\
P2 & 10.75 & 0.46 & 4.34 & 597.69 & 6.66 & 619.89 & $\mathrm{P} 19$ & 33.56 & 1.48 & 10.79 & 1143.43 & 11.89 & 1201.15 \\
P3 & 17.09 & 0.50 & 9.87 & 774.98 & 9.69 & 812.13 & $\mathrm{P} 20$ & 4.52 & 0.42 & 7.23 & 538.37 & 5.86 & 556.40 \\
P4 & 11.98 & 0.40 & 8.22 & 641.64 & 6.75 & 668.99 & $\mathrm{P} 21$ & 5.39 & 0.31 & 6.08 & 477.07 & 5.97 & 494.81 \\
P5 & 29.02 & 1.73 & 8.55 & 697.67 & 11.11 & 748.09 & $\mathrm{P} 22$ & 17.81 & 0.73 & 6.86 & 526.79 & 5.53 & 557.72 \\
P6 & 8.28 & 0.85 & 6.18 & 655.57 & 6.82 & 677.70 & $\mathrm{P} 23$ & 6.68 & 0.31 & 5.13 & 669.89 & 4.59 & 686.60 \\
P7 & 11.58 & 0.53 & 9.05 & 673.78 & 7.33 & 702.28 & $\mathrm{P} 24$ & 10.17 & 0.69 & 6.18 & 588.57 & 6.07 & 611.68 \\
P8 & 4.80 & 0.33 & 6.60 & 518.01 & 6.48 & 536.22 & $\mathrm{P} 25$ & 25.31 & 0.97 & 8.38 & 706.04 & 6.48 & 747.18 \\
P9 & 3.55 & 1.59 & 15.04 & 1155.78 & 12.14 & 1188.12 & $\mathrm{P} 26$ & 60.13 & 1.09 & 8.67 & 438.68 & 5.59 & 514.16 \\
P10 & 6.74 & 0.32 & 5.27 & 688.96 & 4.72 & 706.01 & $\mathrm{P} 27$ & 33.71 & 0.65 & 5.97 & 465.65 & 3.92 & 509.89 \\
P11 & 8.35 & 0.69 & 6.25 & 595.81 & 6.14 & 617.25 & $\mathrm{P} 28$ & 24.43 & 1.27 & 5.85 & 332.69 & 4.99 & 369.22 \\
P12 & 10.27 & 0.48 & 7.28 & 622.50 & 5.55 & 646.08 & $\mathrm{P} 29$ & 13.62 & 0.81 & 4.01 & 327.31 & 5.21 & 350.96 \\
P13 & 21.88 & 1.05 & 9.33 & 411.27 & 6.50 & 450.03 & $\mathrm{P} 30$ & 14.12 & 0.78 & 8.09 & 375.60 & 6.72 & 405.31 \\
P14 & 8.67 & 0.73 & 6.44 & 618.85 & 6.49 & 641.17 & $\mathrm{P} 31$ & 17.63 & 0.91 & 9.80 & 452.72 & 6.81 & 487.88 \\
P15 & 4.08 & 0.47 & 4.51 & 621.34 & 6.92 & 637.32 & $\mathrm{P} 32$ & 16.08 & 0.74 & 6.36 & 491.61 & 4.82 & 519.61 \\
P16 & 6.85 & 0.38 & 7.61 & 597.07 & 7.47 & 619.39 & $\mathrm{P} 33$ & 21.68 & 0.90 & 7.06 & 442.86 & 6.59 & 479.09 \\
P17 & 4.15 & 0.40 & 8.36 & 652.68 & 6.87 & 672.47 & $\mathrm{P} 34$ & 19.16 & 0.92 & 8.17 & 360.13 & 5.69 & 394.07 \\
\hline
\end{tabular}

which metal has this higher $\mathrm{CF}$ because it is specific for each one which were classified in decreasing order of toxicity $(\mathrm{Cd}=30>\mathrm{Cu}=\mathrm{Pb}=5>\mathrm{Cr}>\mathrm{Zn}=1)$.

As a predict model, the PERI is dependent on calibration with bio-indicators in order to evaluate its effectiveness for potential risk of soil heavy metals. The PERI application in Bahr El Baqar ecosystems was successful, demonstrating that the environmental variables used in the algorithm proposed by (Hakanson 1980) are the main integrator parameters of biogeochemical processes in this ecosystem. In addition, the relationship among these variables shows a logical synthesis of biogeochemical processes that influence metal behavior in the soils. In this study, spatial distribution of $\mathrm{Cd}$ in all study areas was investigated. $\mathrm{Cd}$ was chosen because it represents up to $90 \%$ of PERI (Table 9) values for almost all study areas, being representative of metal bioavailability and their risks in these areas. 
Table 10 Fitted parameters of the variogram models for heavy metals

\begin{tabular}{|c|c|c|c|c|c|c|}
\hline \multirow[t]{2}{*}{ Parameters } & \multirow[t]{2}{*}{ Models } & \multicolumn{5}{|c|}{ Prediction errors } \\
\hline & & Mean & Root mean square & $\begin{array}{l}\text { Average } \\
\text { standard error }\end{array}$ & Mean standardized & $\begin{array}{l}\text { Root mean square } \\
\text { standardized }\end{array}$ \\
\hline $\mathrm{DC}$ & K-Bessel & -0.1088 & 3.4394 & 3.9591 & 0.0051 & 0.9018 \\
\hline MPI & Exponential & -0.0003 & 0.0363 & 0.0388 & 0.0034 & 0.9625 \\
\hline PLI & Exponential & -0.0064 & 0.3253 & 0.3617 & -0.0032 & 0.9503 \\
\hline Cd (by mean) & Pentaspherical & -0.0875 & 2.1092 & 2.2170 & -0.0057 & 0.9914 \\
\hline Cd (by CF) & Rational quadratic & -0.1598 & 3.5015 & 3.74614 & -0.0076 & 0.9535 \\
\hline Cd (by I-geo) & Stable & -0.0078 & 0.2070 & 0.2158 & -0.0077 & 0.9727 \\
\hline PERI & Pentaspherical & 1.3035 & 185.3357 & 191.9156 & -0.0037 & 0.9862 \\
\hline
\end{tabular}

\section{Spatial distribution of soil heavy metals}

Table 10 and Fig. 3 list the cross validation and fitted parameters results in examining the validity of the different models and parameters of semivariograms (e.g., $\mathrm{Cd}$ parameters, single and combined index). Cross-validation was used for comparing the interpolation methods. Three indices were calculated from the measured and interpolated values at each validation sample site. The mean error (ME), the mean absolute error (MAE) and the root mean square error (RMSE) are determined from the measured values. The ME is a measure of the bias of the interpolation, which should be close to zero for unbiased methods, and the MAE as well as RMSE are accuracy measures of the interpolation, which should be as small as possible for accurate interpolation.

For the DC index the best fit is the K-Bessel model (SME 0.0051) and Exponential model for MPI and PLI index with a 0.0034 and -0.0032 SME respectively which is closest to zero. The RMSS values for MPI and PLI are 0.9625 and 0.9603 , respectively, which are closest to 1 . The best fit for the mean cadmium parameter is the Pentaspherical model (SME - 0.0057) and Rational Quadratic model for cadmium (by $\mathrm{CF}$ ) with a $-0.0076 \mathrm{SME}$ which is closest to zero. The best fit for the PERI index is the Pentaspherical model (SME -0.0037). When the average estimated prediction standard errors are close to the rootmean-square prediction errors from cross-validation, you can be confident that the prediction standard errors are appropriate (Johnston et al. 2001).

Table 10 lists cross validation results in examine the validity of the fitting models and parameters of semivariograms for heavy metals. Table 10 shows the most suitable models and their prediction error values for each parameter. Table 10 also shows that for the different parameters, different models may give better results. For heavy metals, RMSS range from 0.9018 to 0.9862 . Figures 4 and 5 shows the spatial distribution maps of different indices (e.g., DC, PLI, MPI, PERI....) in the study area based on these interpolations.

From the point of integrated assessments view, the ecological risk of heavy metals in the surface soils for the study area indicating a high contamination risk which was dominated by Cd (Fig. 5).

\section{Overall discussion}

Recall, the principal objective of this study was to assess soil contamination in Bahr El Baqar agricultural area. The discharge of industrial, agricultural and municipal wastewaters in Bahr El Baqar drain has contaminated the environment surrounding Bahr El Baqar areas. The fieldwork was conducted during the dry season in order to obtain maximal heavy metal concentration from the soil. (Yahaya et al. 2009) confirmed that the concentration of heavy metal in soil is higher in the dry season than in a rainy season because heavier metals are lost in the soil due to run-off and infiltration in a rainy season. The accumulation of heavy metals in these soils is a serious concern due to their persistence and toxicity. Thirty-four samples were collected at $0-20 \mathrm{~cm}$ and evaluated for heavy metals using geoaccumulation index (I-geo), enrichment factor (EF) and contamination factor (CF), pollution load index (PLI), and metal pollution index (MPI), etc.

The concentration of cadmium ranges from 10.27 to $19.07 \mathrm{mg} / \mathrm{kg}$ with a mean concentration of $14.69 \mathrm{mg} / \mathrm{kg}$. The calculated geo-accumulation index (I-geo) for cadmium indicates that the soils are extremely contaminated and very high contamination degree with the $\mathrm{CF}$ index. $\mathrm{Cd}$ is regarded as one of the most toxic trace elements in the environment. $\mathrm{Cd}$ is higher in the study area because of the uses of phosphate fertilizers, irrigation by untreated wastewater of Bahr El Baqar darin. Therefore, the water from this drain is not suitable for agricultural purposes. Manganese ranged from 13.73 to $98.73 \mathrm{mg} / \mathrm{kg}$. The mean was $58.98 \mathrm{mg} / \mathrm{kg}$. The calculated I-geo value gave a value 


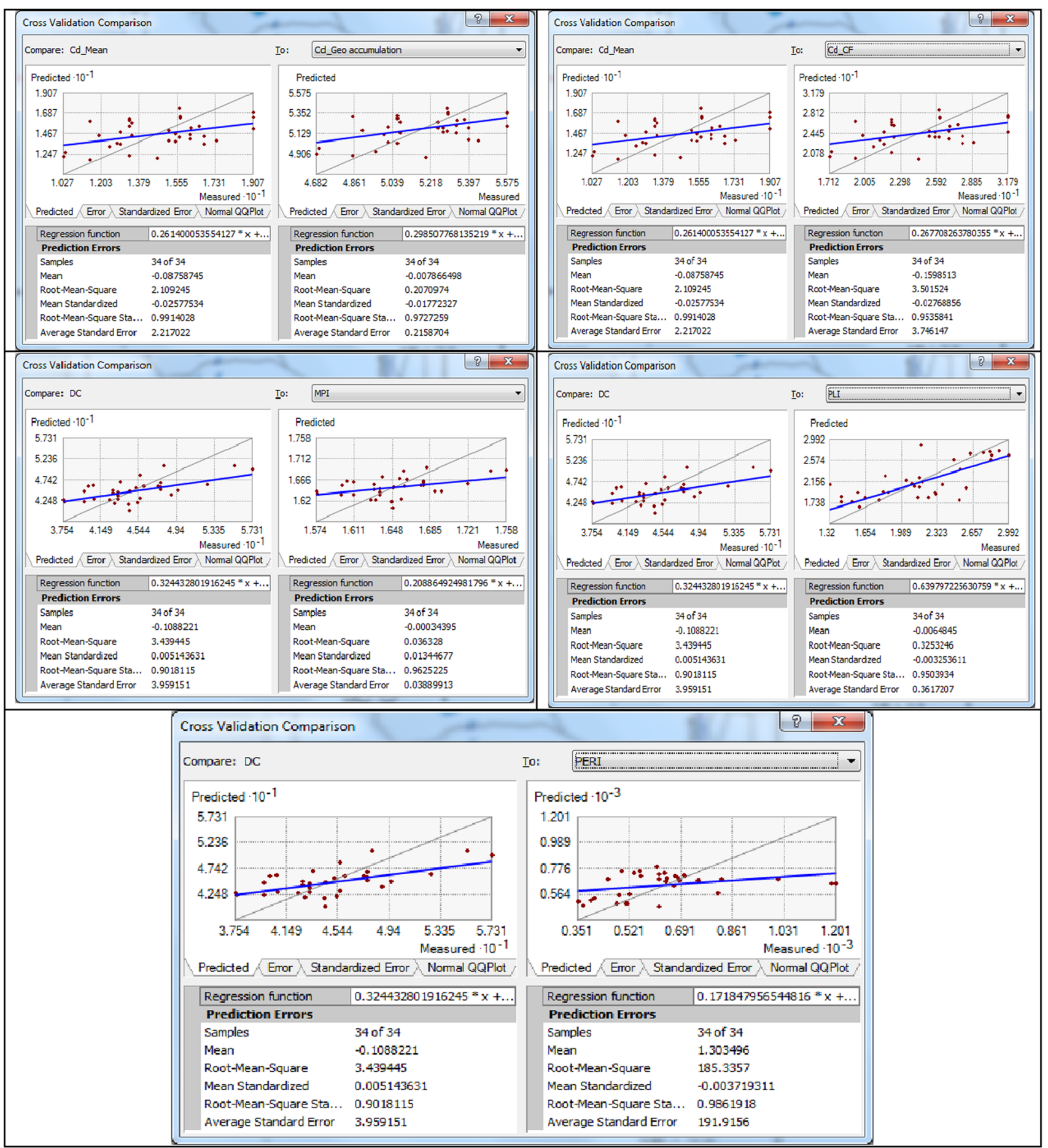

Fig. 3 The cross validation comparison of the soil heavy metals map by different methods

that indicates uncontaminated to moderate and low contamination degree with the $\mathrm{CF}$ index. Manganese can be adsorbed onto soil depending on organic content, $\mathrm{pH}$, grain-size and cation exchange capacity of the soil and this can be exemplified by the strong positive correlation with organic matter $(<0.01$ level). The concentration of copper varied from 7.73 to $280.30 \mathrm{mg} / \mathrm{kg}$ with an average value of $65.70 \mathrm{mg} / \mathrm{kg}$. A moderately positive, high correlation with lead and Zinc was established $(<0.01$ level). Although zinc remains adsorbed to soil, leaching has been reported at waste disposal sites. The lower concentrations of the $\mathrm{Zn}$ might be due to the continuous removal of heavy metals by 

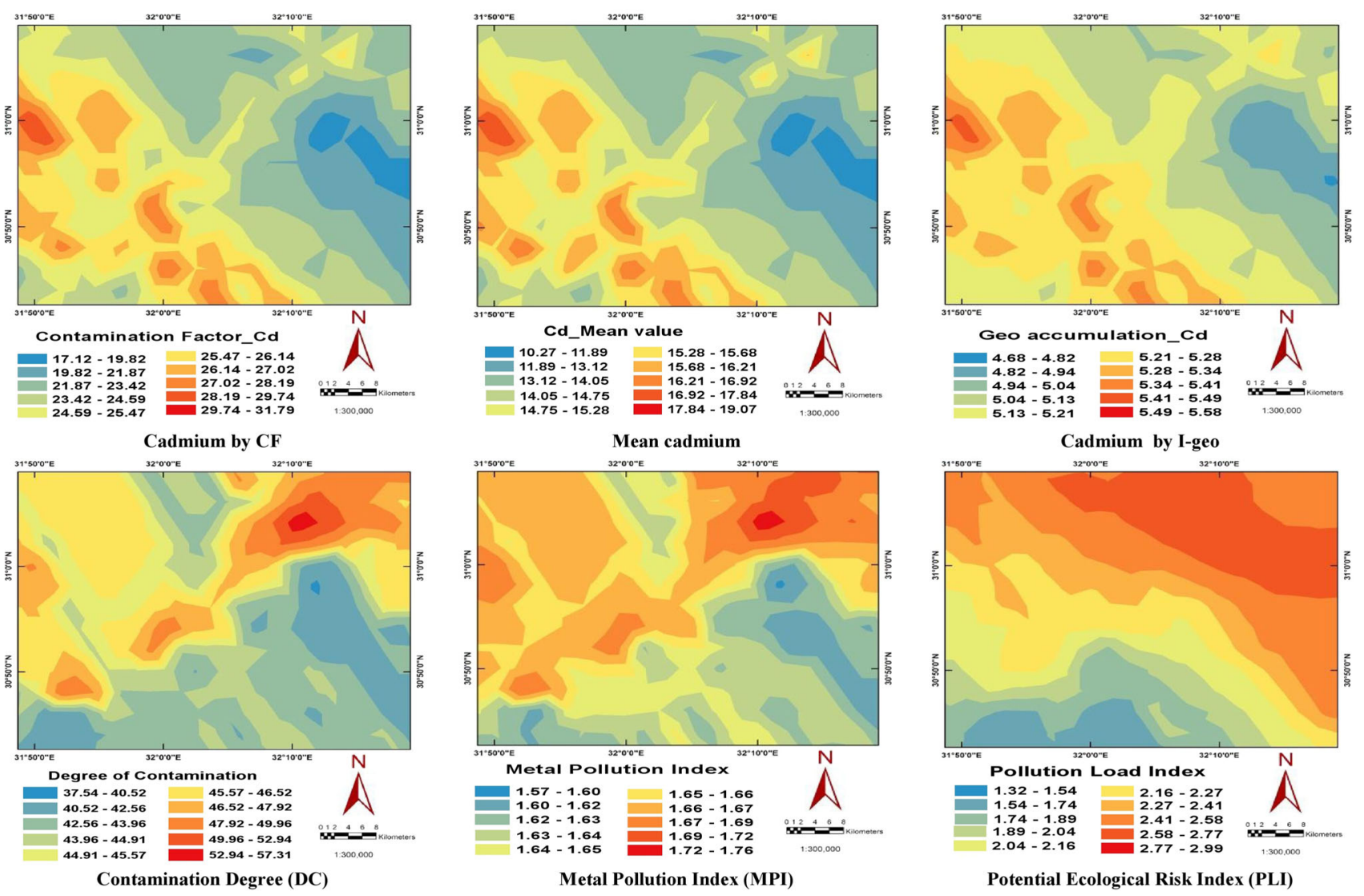

Fig. 4 Spatial distribution maps of different models

the crops grown and due to leaching of heavy metals into the deeper layer of the soil and in to the ground water. Chromium concentration ranges from 84.92 to $134.06 \mathrm{mg} /$ $\mathrm{kg}$ with a mean value of $106.96 \mathrm{mg} / \mathrm{kg}$. Chromium may be lower in some sites due to the continuous removal of heavy metals by the crops and due to leaching of heavy metals into the deeper layer of the soil and to the ground water. No correlation was found with other metals and its concentration falls within the contaminated. Nickel measured concentrations (61.32-88.73 with mean 73.22) are above the average reference abundance in an uncontaminated soil. A moderate positive correlation with $\mathrm{Zn}$ was noted at $<0.05$ level. The results show that lead concentration ranged from 24.42 to $52.40 \mathrm{mg} / \mathrm{kg}$ with a mean concentration of $36.64 \mathrm{mg} / \mathrm{kg}$. Though there was an observed strong correlation with $\mathrm{Cu}(<0.01$ level), its concentration is within the level of uncontaminated soil. $\mathrm{Zn}$ concentration varied between $39.67 \mathrm{mg} / \mathrm{kg}$ and $215.58 \mathrm{mg} / \mathrm{kg}$ with an average concentration of $90.56 \mathrm{mg} / \mathrm{kg}$. These values are found to be low the average abundance for an uncontaminated soil. The I-geo concentration lies below the range of uncontaminated soil. Zinc had very strong positive correlation with $\mathrm{Cu}$ and $\mathrm{Pb}(<0.01$ level $)$ and moderate positive correlation with $\mathrm{Ni}(<0.05$ level). The irrigation by Bahr El
Baqar wastewater and uses of agricultural fertilizers led to the increasing the $\mathrm{Ni}$ concentrations. Cobalt concentration ranged $70.51-113.82 \mathrm{mg} / \mathrm{kg}$ with a mean value of $89.72 \mathrm{mg} / \mathrm{kg}$. The measured concentrations of Co are in range of contaminated soil. The irrigation of agricultural lands with untreated water led to the accumulation of $\mathrm{Co}$ in the soils. Among significant variables that control the distribution and enrichment of heavy metals in the soils are soil $\mathrm{pH}$, grain size of the soil, amount of organic matter in the soil and the cation exchange capacity (Huang and Lin 2003; Lin et al. 2002). The soil $\mathrm{pH}$ is generally high (7.58-8.82) while $\mathrm{CaCO}_{3}(0.61-29.2)$ characterize the top soil and these condition enhances the precipitation and bioaccumulation of heavy metals in soil. Heavy metals have a strong affinity for organic content, clay and silt fraction because of their high cation exchange capacity (Bodur and Ergin 1994; Zonta et al. 1994). The topsoil comprises organic content (0.22-3.55), clay and silt fraction.

Four principal components (Eigenvalues $>1$ ) emerged accounting for $78.11 \%$ of the cumulative variance from the principal component analysis. The first principal component (PC-1) loading with $47.24 \%$ variance showed higher loading for $\mathrm{Cd}, \mathrm{Cu}, \mathrm{Co}, \mathrm{Fe}$ and organic matter. The second principal component (PC-2) has loading $13.65 \%$ of 
Fig. 5 Prediction maps of the potential ecological risk index (PERI)

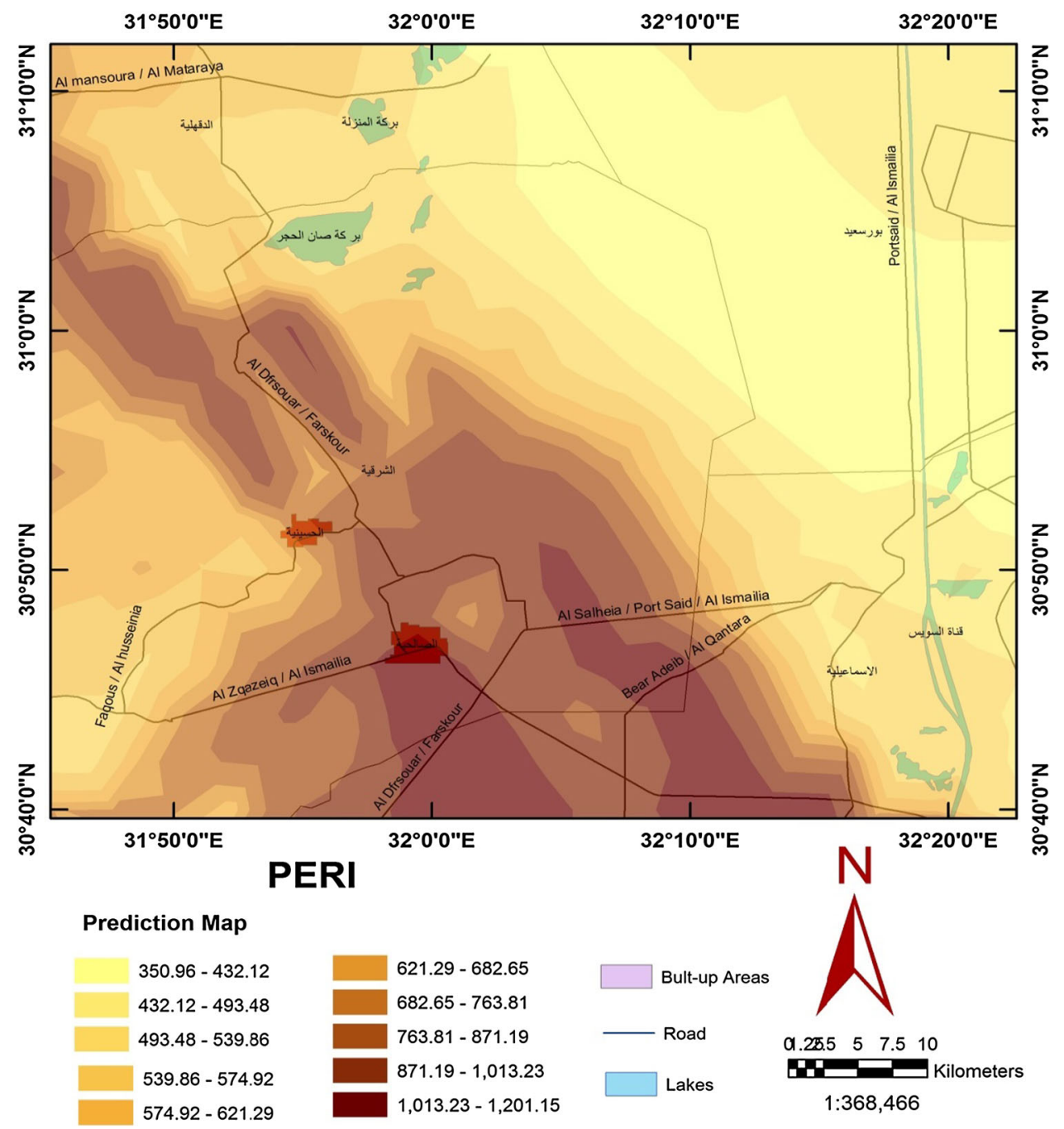

the total variance, had high loading. The $\mathrm{pH}$ of the soil could have contributed to $\mathrm{Pb}$ and $\mathrm{Zn}$ retention in the soil, resulting in low mobility of the metals (Amadi et al. 2012; Yoshida et al. 2002). The third principal component (PC-3) explains $10.72 \%$ of the total variance and consists of silt, clay, $\mathrm{CaCO}_{3}, \mathrm{CEC}, \mathrm{OM}$ and $\mathrm{pH}$. The fourth principal component (PC-4) has a moderate loading for $\mathrm{Mn}$, and $\mathrm{Zn}$, which accounts for $6.49 \%$ of the total variance. Industrial activities domiciled in the area may be responsible for the presence of $\mathrm{Mn}$ and $\mathrm{Zn}$. The physico-chemical properties of clay could have encouraged their availability in the soil. By applying the Pearson rank order correlations, Fe is well correlated with $\mathrm{Mn}$ and moderately correlated with $\mathrm{Cu}$ and $\mathrm{Zn}$. There is a good correlation between Ni and Co. There are significant correlations between $\mathrm{Cu}$ and each of $\mathrm{Zn}$ and $\mathrm{Pb}$. $\mathrm{Ni}, \mathrm{Fe}, \mathrm{Mn}, \mathrm{Cu}, \mathrm{Zn}$ and $\mathrm{Co}$ are positively correlated with $\mathrm{OM}, \mathrm{pH}$, clay, $\mathrm{CaCO}_{3}$, and $\mathrm{CEC}$ and of course negatively correlated with sand. These results revealed that these heavy metals in the soils have the same source of contamination, which is Bahr El Baqar drain.

\section{Conclusions}

This work provides a comprehensive analysis of heavy metal assessment in Bahr El Baqar surface soils. Different indices have been employed for the evaluation of heavy metal contamination status. The impact of anthropogenic heavy metal pollution in the sampling locations was evaluated using Enrichment Factor (EF), Contamination Factor (CF), Contamination degree, Pollution load Index, Metal Pollution Index (MPI), and Geoaccumulation Index (I-geo) at 34 sampling locations of Bahr El Baqar region. The results showed that average $\mathrm{CF}$ values for heavy metals have an order $\mathrm{Cd}>\mathrm{Cr}>\mathrm{Co}>\mathrm{Ni}>\mathrm{Cu}>\mathrm{Pb}>\mathrm{Zn}>$ $\mathrm{Mn}>\mathrm{Fe}$, suggesting that soil samples was extremely highly enriched with $\mathrm{Cd}$, while $\mathrm{Pb}$ exhibit significant enrichment. The results of EF of all sampling sites were found to be less than 2 indicates the study area falls in the category of deficiency to low enrichment. The results of Contamination Factor, and Contamination degree, show that the study area falls under moderate to very high 
contamination degree. Calculation of the pollution load Index, Metal Pollution Index, Metal Contamination Index and Geo accumulation Index indicates the study area is regarded as polluted. The present study suggests that these indices are useful tools for identification of anthropogenic source of soil contamination. Multivariate analysis and correlation matrix were used in this study. A significant positive correlation is observed among $\mathrm{Fe}$ and $\mathrm{Mn}$, and moderately correlated with $\mathrm{Cu}$ and $\mathrm{Zn}$. There is a good correlation between $\mathrm{Ni}$ and $\mathrm{Co}$ indicating that these metals were derived from similar sources. $\mathrm{Ni}, \mathrm{Fe}, \mathrm{Mn}, \mathrm{Cu}, \mathrm{Zn}$ and Co are positively correlated with $\mathrm{OM}, \mathrm{pH}$, clay, $\mathrm{CaCO}_{3}$, and CEC and of course negatively correlated with sand. From the point of integrated assessments of multiple heavy metal pollution, the ecological risk of heavy metals in the surface soils in the study area indicating a high risk, which was dominated by $\mathrm{Cd}$. This study shows that although there were variations in the results of the different indices, the combination indices gave us a comprehensive understanding of heavy metal risks in the surface soils of the Bahr El Baqar region.

\section{References}

Abdel-Shafy HI, Aly RO (2002) Water issue in Egypt: resources, pollution andprotection endeavors. CEJOEM 8:3-21

Abdel-Azeem AMTS, Abdel-Moneim MEI, Hassan MAA, Saleh MY (2007) Effects of long-term heavy metal contamination on diversity of terricolous fungi and nematodes in Egypt-a case study. Water Air Soil Pollut J 186:233-254

Akoto O, Ephraim JH, Darko G (2008) Heavy metal pollution in surface soils in the vicinity of abundant raiway servicing workshop in Kumasi, Ghana. Int J Environ Res 2:359-364

Aksu AE, Yaşar D, Uslu O (1998) Assessment of marine pollution in Izmir Bay: heavy metal and organic compound concentrations in surficial sediments. Transl J Eng Environ Sci 22:387-415

Allison LE, Moodie CD (1965) Carbonate. In: Black CA (ed) Methods of soil analysis, Part 2. Am Soci Agron Madison, WI:1379-1396

Amadi AN, Olasehinde PI, Okosun EA, Okoye NO, Okunlola IA, Alkali YB, Dan-Hassan MA (2012) A comparative study on the impact of avu and ihie dumpsites on soil quality in Southeastern Nigeria. Am J Chem 2:17-23

Bai J et al (2011) Assessment of heavy metal pollution in wetlandsoils from the young and old reclaimed regions in the Pearl River Estuary, South China. Environ Pollut 159:817-824

Bodur MN, Ergin M (1994) Geochemical characteristics of the recent sediment from the Sea of Marmara. Chem Geol 115:73-101

Burgos P, Madejón E, Pérez-de-Mora A, Cabrera F (2006) Spatial variability of the chemical characteristics of a traceelement contaminated soil before and after remediation. Geoderma 130:157-175

Caeiro S, Costa MH, Ramos TB (2005) Assessing heavy metal contamination in sado estuary sediment: an index analysis approach. Ecol Ind 5:151-169

Chapman HD (1965) Cation exchange capacity. In: Black, JA (ed) Method of soil analysis, vol 9. Agronomy, Am Inst Agronomy, Madison, WI:891-901
Chaudhari PR, Gupta R, Gajghate DG, Wate SR (2012) Heavy metal pollution of ambient air in Nagpur City. Environ Monit Assess 184:2487-2496

El Nemr A (2011) Impact, monitoring and management of environmental pollution. Nova Science Publishers Inc, New York, p 638 (ISBN-13: 9781608764877)

El Nemr A, Khaled A, Moneer AA, El Sikaily A (2012) Riskprobability due to heavy metals in bivalve from Egyptian Mediterraneancoast. Egypt J Aquat Res 38:67-75

European Union E (2002) Heavy metals in wastes. European Commission on Environment. http://c.ymcdn.com/sites/www. productstewardship.us/resource/resmgr/imported/Heavy\% 20Metals\%20in\%20Waste.pdf. Accessed 15 May 2015

Gee GW, Bauder JW (1986) Particle size analysis. In: A Klute (ed) Methods of soil analysis. Part 1. Physical and mineralogical methods, 2nd edn. Agron Monogr 9 ASA and SSSA, Madison, WI:383-411

Ghrefat H, Yusuf N (2006) Assessing Mn, Fe, Cu, Zn, and $\mathrm{Cd}$ pollution in bottom sediments of Wadi AL- Arab Dam, Jordan. Chemosphere J 65:2114-2121p

Hakanson L (1980) An ecological risk index aquatic pollution control. A sedimentological approach. Water Res 14:975-1001

Hamed Y, Salem Sh, Ali A, Sheshtawi A (2011) Environmental effect of using polluted water in new/old fish farms, recent advances in fish farms. In: Aral F, Dogğu Z (ed) In Tech. http://cdn. intechopen.com/pdfs-wm/24077.pdf. Accessed 10 Nov 2014

Hasan HAH (2007) Role of rock phosphate in alleviation of heavy metals stress on Fusariumoxysporum. Plant Soil Environ 53:1-6

Hou D, He J, Lü C, Ren L, Fan Q, Wang J, Xie Z (2013) Distribution characteristics and potential ecological risk assessmentof heavy metals $(\mathrm{Cu}, \mathrm{Pb}, \mathrm{Zn}, \mathrm{Cd})$ in water and sediments from LakeDalinouer, China. Ecotoxicol Environ 93:135-144

$\mathrm{Hu}$ Y, Liu X, Bai J, Shih K, Zeng EY, Cheng H (2013) Assessing heavy metal pollution in the surface soils of a region thathad undergone three decades of intense industrialization andurbanization. Environ Sci Pollut Res 20:6150-6159

Huang K, Lin S (2003) Consequences and implication of heavy metal spatial in sediments of Keelung River drainage basin, Taiwan. Chemosphere J 53:1113-1121

Johnston K, Ver Hoef JM, Krivoruchko K, Lucas N (2001) Using ArcGIS Geostat Anal. Environmental Systems Research, Redlands

Jorgensen LA, Pedersen B (1994) Trace Metals in Fish used for Time Trend Analysis and as EnvironmentalIndicators. Mar Pollut Bull 28:235-243

Li H, Qian X, Hu W, Wang Y, Gao H (2013) Chemical speciation and human health risk of trace metals in urban street dusts from a metropolitan city, Nanjing, SE China. Sci Total Environ 456:212-221

Lin YP, Teng TP, Chang TK (2002) Multivariate analysis of soil heavy metal pollution and landscape in Changhua Country in Taiwan. Landsc Urban Plan 62:19-35

Mwamburi J (2003) Variations in trace elements in bottom sediments of major rivers in Lake Victoria's basin, Kenya. Lakes Reserv Res Manag 8:5-13

Ohlson DW, Serveiss VB (2007) The integration of ecological risk assessment and structured decision making into watershed management. Integ Environ Assess Manag 3:118-128

Omran EE (2008) Is soil science dead and buried? Future image in the world of 10 billion people. CATRINA 3:59-68

Omran EE, Abd El Razek AA (2012) Mapping and screening risk assessment of heavy metals concentrations in soils of the Bahr El-Baker Region. Egypt J Soil Sci Environ Manag 6:182-195

Park JH, Shin WS (2006) Immobilization of Pb contamined soil using modified clay. Water Pract Technol 1:1-10 
Praveena MS, Radojevic M, Abdullah MH (2007) The assessment of mangrove sediment quality in mengkabong lagoon: an index analysis approach. Int J Environ Sci Educ 2:60-68

Rubio R, Vilas F (2000) Geochemistry of major and trace elements in sediments of the Ria de Vigo (NW Spain) an assessment of metal pollution. Mar Pollut Bull 40:968-980

Saito H, Goovaerts P (2000) Geostatistical interpolation of positively skewed and censored data in a dioxincontaminated sites. Environ Sci Technol 34:4228-4235

Sedky DM, Khaled A, El Nemr A (2013) Assessment ofpesticides and $\mathrm{PCB}$ in sediments of the Egyptian Mediterranean Coast. Egypt J Aquat Res 39:141-152

Serveiss VB (2002) Applying ecological risk principles to watershed assessment and management. Environ Manag 29:491

Sun YB, Zhou QX, Xie XK, Liu R (2010) Spatial, sources and risk assessment of heavy metal contamination of urban soils in typical regions of Shenyang Chin. J Hazard Mater 17:455-462

Sutherland RA (2000) Bed Sediment Associated Trace Metals in an Urban Stream, Oahu, Hawaii. Environ Geol 39:611-627

Taylor SR (1964) Abundance of chemical elements in the continental crust: a new table. Geochim Cosmochim Acta 28:1273-1285

Thambavani SD, Mageswari UTS (2013) Metal pollution assessment in ground water bulletin of environment. Pharmacol Life Sci 2:122-129

Tijani MN, Onodera S, Adeleye MA (2005) Environmental implications of adsorbed and total trace metals concentrations in bottom-sediments of an urban drainage network in a developing country. Mater Geoenviron 52:127-130p

Tippie VK (1984) An environmental characterization of Chesapeake Bay and a frame work for action. In: Kennedy V (ed) The estuary as a filter. Academic Press, New York

Turekian KK, Wedepohl KH (1961) Distribution of the elements in some major units of the earth's crust. Geol Soc Am Bull 72:16

Usero JA, Garcia J (2000) FraidiasCalidad de lasaguas y sedimentos del LitoralAndaluz in: Junta de Andalicia, Consejeria del Medio Ambiente, Sevilla: 164

Walkley A, Black AI (1934) An examination of the Degtjareff method for determining soil organic matter, and a proposed

Webster R, Oliver MA (2001) Geostatistics for environ-mental scientists. Wiley, West Sussex

Yahaya MI, Mohammad S, Abdullahi BK (2009) Seasonal variation of heavy metal concentration in Abattoir dumpsite soil in Nigeria. J Appl Sci and Environ Manag 13:9-13

Yobouet YA, Adouby K, Trokourey A, Yao B (2010) Cadmium, copper, lead and zinc speciation in contaminated soils. Int J Eng Sci Technol 2:802-812

Yoshida M, Ahmed S, Nebil S, Ahmed G (2002) Characterization of leachate from Henchir El Yahoidia close landfill. Water Waste Environ Res 1:129-142

Zonta R, Zaggia L, Argese E (1994) Heavy metal and grain-size distribution in estuarine shallow water sediments of the Cona Marsh, Venice Lagoon, Italy. Sci Total Environ 151:19-28 